\title{
Plant growth promotion by four species of the genus Burkhoderia
}

\author{
Gabriela Cavalcanti Alves • Aline Vieira de Matos Macedo • Fabio Bueno dos Reis Jr. • \\ Segundo Urquiaga • Veronica Massena Reis
}

Received: 9 March 2015 / Accepted: 6 October 2015 / Published online: 16 October 2015

(C) Springer International Publishing Switzerland 2015

\begin{abstract}
Background and aims The genus Burkholderia is highly diverse and may mediate plant growth via several mechanisms. The current study evaluates the role of strains from four Burkholderia species in maize growth promotion.

Methods Twenty three strains of diazotrophic Burkholderia species were applied to two maize genotypes (SHS5050 and BRS4157) under greenhouse and field conditions. Strains were tested for growth promotion in greenhouse during 40 days. Strain 41 from $B$. silvatlantica was used under field conditions. Parameters evaluated: biomass accumulation, $\mathrm{N}$ and root measurements in pots
\end{abstract}

Responsible Editor: Ian Dodd.

\section{G. C. Alves}

Instituto de Agronomia, Departamento de Solos, Universidade Federal Rural do Rio de Janeiro, BR-465 Km 07., Seropédica CEP 23890-000, Brazil

e-mail: gabrielacalves@yahoo.com.br

A. V. de Matos Macedo - S. Urquiaga • V. M. Reis ( $₫)$ Embrapa Agrobiologia, km 07 BR 465, Seropédica, RJ CEP 23891-000, Brazil

e-mail: veronica.massena@embrapa.br

A. V. de Matos Macedo

e-mail: aline.macedo@embrapa.br

S. Urquiaga

e-mail: segundo.urquiaga@embrapa.br

F. B. dos Reis Jr.,

Embrapa Cerrados, Rodovia BR-020, km 18, Planaltina, DF CEP

73310-970, Brazil

e-mail: fabio.reis@embrapa.br and grain yield, $\mathrm{N} \%$ and $\mathrm{N}$ in the grains under field conditions.

Results Eleven strains were evaluated under soil substrate. The inoculation of the hybrid SHS5050 showed root biomass improvement using three strains, namely M130, M209 and PPe7. The highest acetylene reduction activity was observed in strain 41 from $B$. silvatlantica. Strain 41 from $B$. silvatlantica improved plant dry mass on both genotypes. This strain produced $31 \%$ more aerial tissue and $7 \%$ more root dry mass in the BRS4157 variety than it did in the control. Both genotypes planted at Seropédica, RJ, produced $7 \%$ more grains under field conditions and the variety produced $10.9 \%$ more grains in comparison to the non-inoculated control.

Conclusion Strain 41 from $B$. silvatlantica showed beneficial plant-growth promotion of maize under greenhouse and field experiments specially in a low fertility soil.

Keywords Biological nitrogen fixation - Zea mays . Nitrogen · Bacteria

\section{Introduction}

Maize (Zea mays) is one of the main cereals used worldwide in human and animal nutrition and it has been recently used as a source of biofuel. This crop needs large quantities of nitrogen $(\mathrm{N})$ fertilizer to reach high yields. Approximately $9-11 \mathrm{~kg}$ of $\mathrm{N}$ are necessary to produce each tone of maize (Anuar et al. 1995), but its 
application usually reaches efficiency values below $50 \%$ (Halvorson et al. 2002). Beneficial associations between rhizospheric and endophytic diazotrophic bacteria with plants may promote plant growth by means of different mechanisms, especially by enhancing root biomass and indirectly reducing nitrogen loss or even by contributing with part of its demand (Alves et al. 2015).

Several diazotrophs were isolated from maize plants throughout the years. The first one was Azospirillum brasilense, a widespread bacterium species used as a commercial maize inoculant in several countries such as Argentina, Mexico, Colombia, Egypt, and since 2010, in Brazil (Fages 1994; Hungria et al. 2010; Mehnaz et al. 2010). Several genera of Gram-negative bacteria such as Klebsiella, Pantoea, Herbaspirillum, Stenotrophomonas, as well as Gram-positive bacteria such as Paenibacillus and Bacillus, among others were isolated from maize genotypes in some countries (Roesch et al. 2008; Mehnaz et al. 2010; Montañez et al. 2012; Liu et al. 2012; Ikeda et al. 2013; Rodrigues-Blanco et al. 2015). Burkholderia is one of the genera commonly found in several plants, including maize (Liu et al. 2012). This genus is able to produce nodules in legume species (Moulin et al. 2001) and it is associated with properties that can benefit several plants (Sessitsch et al. 2005). However, it also encompasses species that cause plant, animal and human diseases, especially $B$. cepacia complex - Bcc (Coenye and Vandamme 2003). It is a controversial genus which presents several positive and negative properties and it is divided into Bcc (normally associated with detrimental aspects) and plant-associated nitrogen-fixing groups. Its clade is reported to be beneficial to plants (Suárez-Moreno et al. 2012). It has positive features such as biological nitrogen fixation (BNF), biocontrol by antimicrobial activity compounds production, aromatic pollutants and chlorinated solvents degradation, phytohormones production, among others features (Van et al. 2000; EstradaDe Los Santos et al. 2001; Caballero-Mellado et al. 2007; Paungfoo-Lonhienne et al. 2014). $B$. vietnamiensis belongs to the Bcc complex, but it was isolated from rice rhizosphere in Vietnam. The species is considered to be a plant growthpromoting rhizobacteria (PGPR) (Van et al. 2000). B. kururiensis (Anandham et al. 2009), B. tropica (Reis et al. 2004) and B. silvatlantica (Perin et al. 2006) were isolated from sugarcane and maize in Brazil and México and they are considered to be PGPR bacteria associated with sugarcane, tomato, and pineapple growth, among others plants (Suárez-Moreno et al. 2012).

Burkholderia vietnamiensis is the oldest diazotrophic Burkholdeira species described (Gillis et al. 1995) and it has been mentioned several times as inoculant application in rice crops (Van et al. 2000; Govindarajan et al. 2008). B. kururiensis was first described in a contaminated soil in Japan (Zhang et al. 2000), but its other strain (M130) was also isolated from rice and used as inoculant also in rice (Mattos et al. 2008; Guimarães et al. 2010). It was first described as a new species called B. brasilensis (Baldani et al. 1997). However, this name was not accepted because this strain fitted into the new B. kururiensis species described at that time. This species had the same 16S rRNA gene sequence and did not differ in the other tested molecular and morphological parameters. B tropica is another beneficial species isolated from sugarcane (Reis et al. 2004) and it is applied to this crop as part of a mixed inoculant (Oliveira et al. 2003, 2006; Schultz et al. 2012, 2014). B. silvatlantica is the newest described species in comparison to the other three species (Perin et al. 2006) and it is also the one that had fewer data on plant application.

The Burkholderia species is commonly found in maize plants (Perin et al. 2006). but few studies have examined the impacts of applying different PGPR strains to this plant (Mehnaz et al. 2010). Thus we aimed to assess the application of 23 PGPR strains that belong to genus Burkholderia (from 4 different species - all deposited at the diazotrophic Bacteria Collection of Embrapa Agrobiologia) on maize. Inoculant effects on two maize varieties (the SHS5050 maize hybrid and BRS4157 variety) were assessed under greenhouse and field conditions, in aiming to determine the strain with the best performance under field conditions.

\section{Material and methods}

Organisms

Twenty-three strains of the genus Burkholderia deposited at Embrapa Agrobiologia Diazotrophic Bacteria Collection were used in the current study. These strains encompassed five $B$. kururiensis, four $B$. tropica, five $B$. vietnamiensis and nine $B$. silvatlantica strains (Table 1). All the strains were initially grown on plates with solid JMV culture medium (Baldani et al. 2014). 
Table 1 Sequence identities of isolates tested in maize based on the partial sequence of the 16S rRNA gene

\begin{tabular}{|c|c|c|c|c|}
\hline Isolate & $\mathrm{BR}^{*}$ & Origin & 16S rRNA identity & No. of accession \\
\hline $\mathrm{KP} 23^{\mathrm{T}}$ & 11,897 & aquifer polluted (Japan) & B. kururiensis & NR_024721.1 \\
\hline M130 & 11,340 & Rice & B. kururiensis & AJ238360.1 \\
\hline M209 & 11,345 & Rice & B. kururiensis & KT235803 \\
\hline 100 & 11,815 & Rice & B. kururiensis & KP974789 \\
\hline 120 & 11,821 & Rice & B. kururiensis & KP974790 \\
\hline Ppe5 & 11,363 & Sugarcane & B. tropica & KP974788 \\
\hline Ppe6 & 11,364 & Sugarcane & B. tropica & AF491938.1 \\
\hline Ppe7 & 11,365 & Sugarcane & B. tropica & AF491937.1 \\
\hline Ppe ${ }^{\mathrm{T}}$ & 11,366 & Sugarcane & B. tropica & NR_028965.1 \\
\hline $\mathrm{TVV}^{\mathrm{T}} 5^{\mathrm{T}}$ & 12,311 & Rice (Vietnan) & B. vietnamiensis & NR_118872.1 \\
\hline 75 & 11,807 & Rice & B. vietnamiensis & KP974791 \\
\hline 102 & 11,816 & Rice & B. vietnamiensis & KP974792 \\
\hline 121 & 11,822 & Rice & B. vietnamiensis & KP974793 \\
\hline 139 & 11,826 & Rice & B. vietnamiensis & KP974794 \\
\hline 41 & 12,149 & Rice & B. silvatlantica & KР974795 \\
\hline $3 \mathrm{~m}$ & 11,905 & Maize & B.silvatlantica & KP974787 \\
\hline $78 \mathrm{~m}$ & 11,909 & Maize & B. silvatlantica & KP974780 \\
\hline $85 \mathrm{~m}$ & 11,911 & Maize & B. silvatlantica & КР974781 \\
\hline $89 \mathrm{~m}$ & 11,914 & Maize & B. silvatlantica & KP974782 \\
\hline $90 \mathrm{~m}$ & 11,915 & Maize & B. silvatlantica & KP974783 \\
\hline PPCRr1 & 12,164 & Sugarcane & B. silvatlantica & KP974784 \\
\hline PPCRr3 & 12,165 & Sugarcane & B. silvatlantica & KP974785 \\
\hline PPCRr8 & 12,166 & Sugarcane & B. silvatlantica & KP974786 \\
\hline
\end{tabular}

*BR identification number of the strain deposit in the Diazotrophic Culture Collection of Embrapa Agrobiologia, Brazil. T Type strains

Taxonomic identification

Genomic DNA was extracted from 23 isolates previously cultivated/grown in liquid DYGS medium (Baldani et al. 2014) for $24 \mathrm{~h}$. The DNA was extracted using Wizard Genomic DNA Purification Kit (Promega, Madison, Wisconsin,USA), according to the manufacturer's instructions. The fragment of the 16S rRNA gene was amplified by the 27F (5'-GAGTTTGATCCTGGCTCAG-3') and Amp2 (5'-AAGGAGGTGAT CCARCCGCA-3') primer combination. The PCR mixture consisted of $10 \times$ buffer, $2.0 \mathrm{mM} \mathrm{MgCl}, 0.25 \mathrm{mM}$ DNTP, $0.2 \mu \mathrm{M}$ forward and reverse primers, and $1.5 \mathrm{U}$ Go Taq polymerase (Promega valid data 12/10/15). The reaction was heated at $95^{\circ} \mathrm{C}$ for 3 min, followed by 29 cycles with denaturation at $94{ }^{\circ} \mathrm{C}$ for $45 \mathrm{~s}$ and annealing at $58{ }^{\circ} \mathrm{C}$ for $45 \mathrm{~s}$ with $2 \mathrm{~min}$ extension. The PCR product was quantified and ExoSap treated.

The sequencing reaction was performed using $100 \mathrm{ng}$ DNA, $1.5 \mu 15 \times$ sequencing buffer (Applied Biosystems
Cat 4,336,697), $1 \mu \mathrm{L}$ Big Dye Terminator v3.1 (Applied Biosystems Cat 4,336,917) and $1 \mu$ forward and reverse primers $(5 \mu \mathrm{M})$. The primers used in the sequencing reaction were also 27F and Amp2.

The reaction was carried out starting at $96{ }^{\circ} \mathrm{C}$ for $1 \mathrm{~min}$ and it was followed by 35 cycles involving denaturation at $96{ }^{\circ} \mathrm{C}$ for $15 \mathrm{~s}$ and annealing at $50{ }^{\circ} \mathrm{C}$ for $15 \mathrm{~s}$ with extension at $60{ }^{\circ} \mathrm{C}$ for $4 \mathrm{~min}$. The Applied Biosystem 3500 was used to obtain the sequences.

A similarity search was conducted in the National Center for Biotechnology Information (NCBI) database (http://www.ncbi.nlm.nih.gov). The phylogenetic tree was constructed according to the analysis of $16 \mathrm{~S}$ sequences of diazotrophic bacteria strains. The sequences were aligned using the CLUSTAL W software (Thompson et al. 1994). The phylogenetic analysis was performed using MEGA5 software, with 1450 bases (Tamura et al. 2011), according to the neighbor-joining method (Saitou and Nei 1987) and to 
the Kimura two-parameter model (K2P) (Kimura 1980). Cupriavidus taiwanensis was used as outgroup bacteria.

Nitrogen-fixing ability

The nitrogen-fixing ability was assessed by acetylene reduction assay (ARA), as described by Boddey (1987)using JMV semi-solid culture medium (Baldani et al. 2014) and bromothymol blue $\mathrm{pH}$ indicator, without $\mathrm{N}$. The cultures were incubated in $5 \mathrm{~mL}$ penicillin vials for $72 \mathrm{~h}$ at $30^{\circ} \mathrm{C}$. Nitrogenase activity was determined by ethylene production and measured one hour after acetylene injection. The result was obtained through digital integrator (model 1022 PE Nelson) coupled to the chromatograph. The specific activity was determined by dividing the total ARA activity by the cumulative cell protein of the culture, per hour, according to the method described by Lowry et al. (1951) and modified by Rodrigues et al. (2008). There were three replicates for each bacterial strain and the control had no bacteria.

\section{Selecting Burkholderia spp. strains}

Pure colonies of 23 Burkholderia spp. strains were initially cultured on JMV plates and a single colony was transferred to liquid DYGS culture medium (Baldani et al. 2014) for $24 \mathrm{~h}$, at $30^{\circ} \mathrm{C}$, and stirred on a shaker table at $175 \mathrm{rpm}$. Each seed was treated with $1 \mathrm{~mL}$ cell suspension adjusted to $10^{8}-10^{9}$ colony-forming units $(\mathrm{CFU}) \mathrm{mL}^{-1}$, at the optical density O.D. $436 \mathrm{~nm}=1$ (Schloter et al. 1992). Two experiments were conducted in greenhouse at Embrapa Agrobiologia, in Seropédica, Rio de Janeiro, one using the triple-cross maize hybrid SHS5050 genotype and the other using the BRS4157 variety. The two genotypes were chosen due to their contrasting responses to mineral fertilization and adapted to the regions used for the field experiments. Both experiments were arranged in randomized block design with four replications.

\section{Experiment I}

Plastic boxes were filled with $15 \mathrm{~kg}$ of sand and vermiculite $(2: 1 ; v / v)$ sterilized through vertical autoclave. The results from the substrate analysis were: $\mathrm{pH}$ (water) 4.7. and exchangeable elements ( $\mathrm{cmolc} \mathrm{dm}^{-3}$ ): $\mathrm{Al}, 0.2 ; \mathrm{Ca}+$ $\mathrm{Mg}, 0.9 ; \mathrm{Ca}$ and $\mathrm{Mg}$, not detected and available $\mathrm{P}$ (Mehlich 1), $3.0 \mathrm{mg} \mathrm{dm}^{-3} \mathrm{~K}, 10.0 \mathrm{mg} \mathrm{dm}^{-3}$ and there were no traces of organic matter or $\mathrm{N}$. Soil $\mathrm{pH}$ was corrected by the addition of $\mathrm{CaCO}_{3}$ and $\mathrm{MgSO}_{4}$ to reach the level of $3 \mathrm{cmolc}^{-3}$. Soil fertility was corrected with $80 \mathrm{~kg} \mathrm{ha}^{-1} \mathrm{P}_{2} \mathrm{O}_{5}\left(1.5 \mathrm{mg} \mathrm{kg}^{-1}\right.$ simple superphosphate) and $40 \mathrm{~kg} \mathrm{ha}^{-1} \mathrm{~K}_{2} \mathrm{O}\left(0.2 \mathrm{mg} \mathrm{kg}^{-1} \mathrm{KCl}\right)$. Subsequently, four seeds per box were planted $3 \mathrm{~cm}$ deep. All the inoculated treatments were fertilized with $20 \mathrm{~kg} \mathrm{ha}^{-1} \mathrm{~N}$ (10 mg N kg$)^{-1}$ ) in the form of urea and the control treatments were consisted as one control without inoculant and nitrogen fertilization (T0) and two non-inoculated controls fertilized with $20\left(10 \mathrm{mg} \mathrm{kg}^{-1}-\mathrm{T} 20\right)$ and 40 (20 $\left.\mathrm{mg} \mathrm{kg}^{-1}-\mathrm{T} 40\right) \mathrm{kg} \mathrm{ha}^{-1} \mathrm{~N}$. Forty days after planting, the plants were harvested and the cumulative dry matter (DM) of the shoots and roots was evaluated. The root length and area were measured by the root analysis program developed by Embrapa Instrumentação Agropecuária (SIARCS 3.0). The shoot $\mathrm{N}$ content was determined by Kjeldahl, as suggested by Bremner and Mulvaney (1982).

\section{Experiment II}

Plastic boxes were filled with $15 \mathrm{~kg}$ of soil from the upper $20 \mathrm{~cm}$ of the A horizon of a very N-poor Typic Hapladult (USDA, Soil Taxonomy - Dystrophic Haplic Planosol Ecology series - Brazilian Soil Classification System), of the experimental area at Embrapa Agrobiologia, in Seropédica (22 $44^{\prime} 38^{\prime \prime} \mathrm{S}$ and $43^{\circ} 42^{\prime 2} 8^{\prime \prime} \mathrm{W}$ at $26 \mathrm{~m}$ high). Results from soil analysis were: $\mathrm{pH}$ (water) 4.9 and exchangeable elements in cmolc $\mathrm{dm}^{-3}: \mathrm{Al}, 0.2 ; \mathrm{Ca}+\mathrm{Mg}$, 2.7; Ca, 1.1; Mg, 1.6 and available (Mehlich 1) $\mathrm{P}$, $14.0 \mathrm{mg} \mathrm{dm}^{-3} ; \mathrm{K}, 24.0 \mathrm{mg} \mathrm{dm}^{-3} ; 7.9 \mathrm{mg} \mathrm{dm}^{-3}$ of organic matter and there were no traces of available nitrogen. Soil $\mathrm{pH}$ was corrected as mentioned above and fertility was corrected using $60 \mathrm{~kg} \mathrm{ha}^{-1} \mathrm{P}_{2} \mathrm{O}_{5}\left(1.5 \mathrm{mg} \mathrm{kg}^{-1}\right.$ simple superphosphate) and $40 \mathrm{~kg} \mathrm{ha}^{-1} \mathrm{~K}_{2} \mathrm{O}\left(0.2 \mathrm{mg} \mathrm{kg}^{-1} \mathrm{KCl}\right)$. All the inoculated treatments were fertilized with $20 \mathrm{~kg} \mathrm{ha}^{-1}$ $\mathrm{N}\left(10 \mathrm{mg} \mathrm{N} \mathrm{kg}{ }^{-1}\right)$ in the form of urea and the checks consisted of one control without inoculant and nitrogen fertilization (T0) and two non-inoculated controls fertilized with 20 (10 $\mathrm{mg} \mathrm{kg}^{-1}$ - T20) and $40\left(20 \mathrm{mg} \mathrm{kg}^{-1}\right.$ - T40) kg $\mathrm{ha}^{-1} \mathrm{~N}$. Subsequently, two seeds of each genotype described above were planted per box. The same variables were herein evaluated as they were in Experiment 1.

\section{Field experiments}

Inoculation tests were evaluated according to the ARA activity in sterile and soil substrates in the greenhouse. Strain 41 from Burkholderia silvatlantica was selected for agronomic evaluations under field condition. Thus, 
two field experiments were carried out. The first was conducted on a Typic Hapladult in the experimental area of Embrapa Agrobiologia, the same area used in Experiment II. Results from soil analysis $(0-15 \mathrm{~cm}$ depth) performed before the corrections were: $\mathrm{pH} 5.6$ and nutrient contents in cmolc $\mathrm{dm}^{-3}$ of: $\mathrm{Al}, 0.0 ; \mathrm{Ca}+$ $\mathrm{Mg}, 3.1$; Ca, 1.9; $\mathrm{Mg}, 1.1$; exchangeable $\mathrm{K}$, $48.4 \mathrm{mg} \mathrm{dm}^{-3}$; available (Mehlich 1) P, $4.8 \mathrm{mg} \mathrm{dm}^{-3}$ and $12.0 \mathrm{mg} \mathrm{dm}^{-3}$ of organic matter and $0.57 \mathrm{~g} \mathrm{~kg}^{-1}$ of available nitrogen. A response to $\mathrm{N}$ application is expected in this very $\mathrm{N}$-poor soil in the field condition allows evaluating the potential response to bacteria inoculation. Soil fertility was improved by fertilization with $80 \mathrm{~kg} \mathrm{ha}^{-1} \mathrm{P}_{2} \mathrm{O}_{5}$ (400 kg ha ${ }^{-1}$ simple superphosphate) and $20 \mathrm{~kg} \mathrm{ha}^{-1} \mathrm{~K}_{2} \mathrm{O}\left(33 \mathrm{~kg} \mathrm{ha}^{-1} \mathrm{KCl}\right)$. The second field experiment was carried out on Ultisol (USDA, Soil Taxonomy - Dystrophic Red Latosol Brazilian Soil Classification System), in the experimental area of Embrapa Cerrado, Planaltina, DF. Results from soil analysis (0-15 cm depth) performed before the corrections were: $\mathrm{pH} 5.6$ and nutrient contents in cmolc $\mathrm{dm}^{-3}$ of: $\mathrm{Al}: 0.1, \mathrm{Ca}+\mathrm{Mg}: 2.3$, exchangeable $\mathrm{K}$ : $121.5 \mathrm{mg} \mathrm{dm}^{-3}$; available (Mehlich 1) P, $18.6 \mathrm{mg} \mathrm{dm}^{-3}$ and $16.2 \mathrm{mg} \mathrm{dm}^{-3}$ of organic matter and undetected available nitrogen. Soil fertility was improved by fertilization with $150 \mathrm{~kg} \mathrm{ha}^{-1} \mathrm{P}_{2} \mathrm{O}_{5}\left(750 \mathrm{~kg} \mathrm{ha}^{-1}\right.$ simple superphosphate) and $80 \mathrm{~kg} \mathrm{ha}^{-1} \mathrm{~K}_{2} \mathrm{O}\left(133 \mathrm{~kg} \mathrm{ha}^{-1}\right.$ $\mathrm{KCl}$ ), with addition of $20 \mathrm{~kg} \mathrm{ha}^{-1} \mathrm{~N}$ ( $\mathrm{kg} \mathrm{ha}^{-1}$ of urea). Strain 41 was initially plate-cultured with JMV solid medium to check purity. It was subsequently grown in DYGS medium to obtain cells for field application. The inoculum containing $10^{9}$ cells $\mathrm{mL}^{-1}(75 \mathrm{ml})$ was mixed with $175 \mathrm{~g}$ peat, finely powdered, previously neutralized and autoclaved, and then it was homogenized. The seeds were covered with $10 \%$ manioc starch solution and then covered with peat, inoculated at the ratio of $250 \mathrm{~g}$ peat inoculant per $10 \mathrm{~kg}$ maize seed. The mean monthly temperatures ranged from 20.2 to $24.9{ }^{\circ} \mathrm{C}$ in the 120 days of the experimental period and rainfall ranged from 82.8 to $1.8 \mathrm{~mm}$ in Seropédica. In Planaltina, the mean monthly temperatures ranged from 18.6 to $21.8^{\circ} \mathrm{C}$ and rainfall ranged from 141.7 to $0.10 \mathrm{~mm}$. Both experiments were conducted with the same period of maize growth. Soil moisture was maintained with supplemental irrigation during the low rainfall period. The planting density was 5 plants per $\mathrm{m}^{-2}$. The same genotypes were used in the greenhouse tests. The experiments were arranged in randomized blocks with four replications per treatment, in plots consisting of five $6 \mathrm{~m}$ rows spaced $1 \mathrm{~m}$ apart from each other, with area of $10 \mathrm{~m}^{2}$. Nitrogen fertilization was applied at the rates of 40 and $80 \mathrm{~kg} \mathrm{ha}^{-1}$, half the dose and the recommended $\mathrm{N}$ dose to the crop, split in two half-rate applications in the form of urea. The following variables were analyzed: yield (dry grain weight at $13 \%$ humidity $-\mathrm{kg} \mathrm{ha}^{-1}$ ), $\mathrm{N} \%$ and total $\mathrm{N}$ in grain per plot under $\mathrm{N}$-fertilization. Total $\mathrm{N}$ was determined by digestion as described by Bremner and Mulvaney (1982).

Statistical analysis

The data were analyzed using the SAEG 9.0 software (Euclydes 2004) for normality test (Lilliefors) and variance homogeneity (Cockran \& Bartlet). Variance analyses were then performed in the SISVAR 5.3 software (Ferreira 2010). The Scott-Knott test (Scott \& Knott 1974) was used at $5 \%$ significance level in all the assessments. Correlation analysis was also conducted between the growth-promoting effect and the amount of acetylene reduction (ARA).

\section{Results}

Burkholderia is a genus of the class betaproteobacteria, which comprises more than 85 described species. This number keeps increasing year after year. The current study selected four species - B. kururiensis, B. tropica, $B$. vietnamiensis and $B$. silvatlantica - in order to evaluate their growth promotion effect on maize. All the isolates were obtained from Embrapa Agrobiologia Diazotrophic Culture Collection, RJ and 22 of them originated from plant samples. Only B. kururiensis $\mathrm{KP} 23^{\mathrm{T}}$ strain was isolated from aquifer polluted, it means, an environment strain. Five strains were homologue to maize plants, it means, isolated from the same plant tested and all of them belonged to the species $B$. silvatlantica, which is the latest species described, among the 23 tested species (Table 1).

The phylogenetical tree of the 23 isolates confirms the identity and distance between the strains (Fig. 1). The four species selected for the assay have a different branch in the tree. $B$. silvatlantica is closely related to Burkholderia nodosa and B. tropica to B. unamae, but $B$. viatnamiensis is located in a distant branch and it is considered to be in the B. cepacea cluster.

Acetylene reduction activity is used as indirect method to measure nitrogenase activity. It uses a competitive 
Fig. 1 Neighbor-joining phylogenetical tree based on bacterial 16S rRNA sequences ( $1450 \mathrm{bp}$ ), including sequences used in this study and from the most closely related $16 \mathrm{~S}$ rRNA genes of previously cultured diazotrophic strains. The $16 \mathrm{~S}$ rRNA sequences of the representative isolates used in this study are shown in bold. The $16 \mathrm{~S}$ rRNA sequences of type strains are followed by the letter $\mathrm{T}$. Numbers on the branches represent bootstrap values from 1000 replicates. The bar chart shows the number of nucleotide substitutions per site. Cupriavidus taiwanensis sequences were used as outgroup. Similarity analysis by the program MegaBLAST

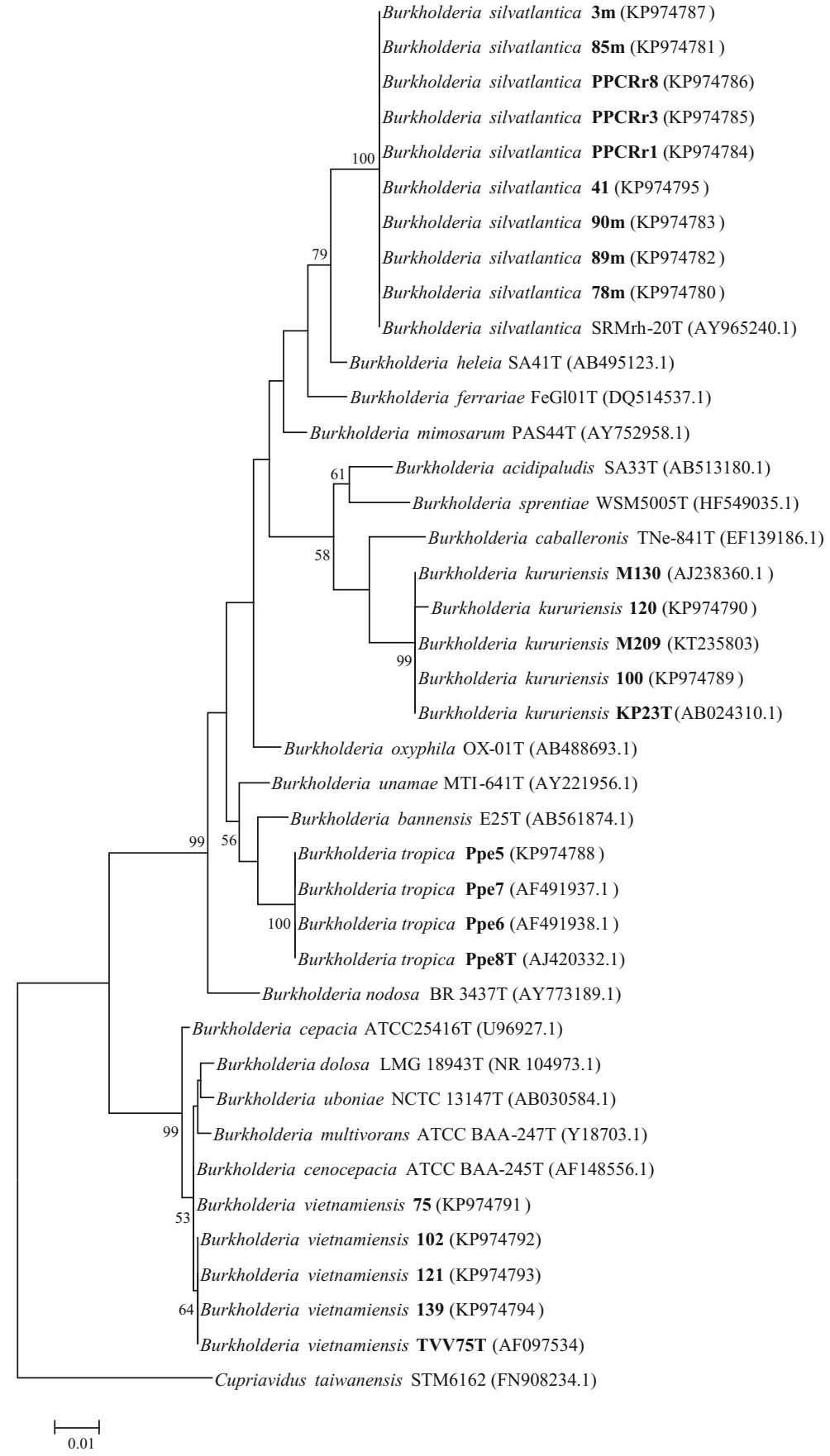

acetylene substrate reduced to ethylene and it is considered to be a good nitrogenase presence indicator. Three days after the inoculation it was applied to all the tested strains in semi-solid medium without nitrogen, when the pellicle was formed as described by Baldani et al. (2014). The ARA among the strains ranged from 8.82 to $905.42 \mathrm{nmol} \mathrm{C}_{2} \mathrm{H}_{4}$ hour $^{-1} \mathrm{mg} \mathrm{ptn}^{-1}$ and the activity was not correlated with plant origin or bacterial species. The low activity $<99$ nmol etylene $\mathrm{h}^{-1} \mathrm{mg}_{\text {prot }}{ }^{-1}$ included 13 strains, the medium activity (100 to 300 ) included 4, and the high activity $(>300)$ included 6 strains (Fig. 2). Two B. kururiensis strains (KP23 and M130), two B. tropica strains (PPe 6 and PPe 7) and two B. silvatlantica strains (41 and PPCRr8) fit this last 
Fig. 2 Nitrogenase activity (ARA) of Burkholderia spp. isolates; values indicate the mean of three replications. Different letters differ significantly by the Scott-Knott test at $5 \%$ probability. $\mathrm{CV}=17,31 \%$

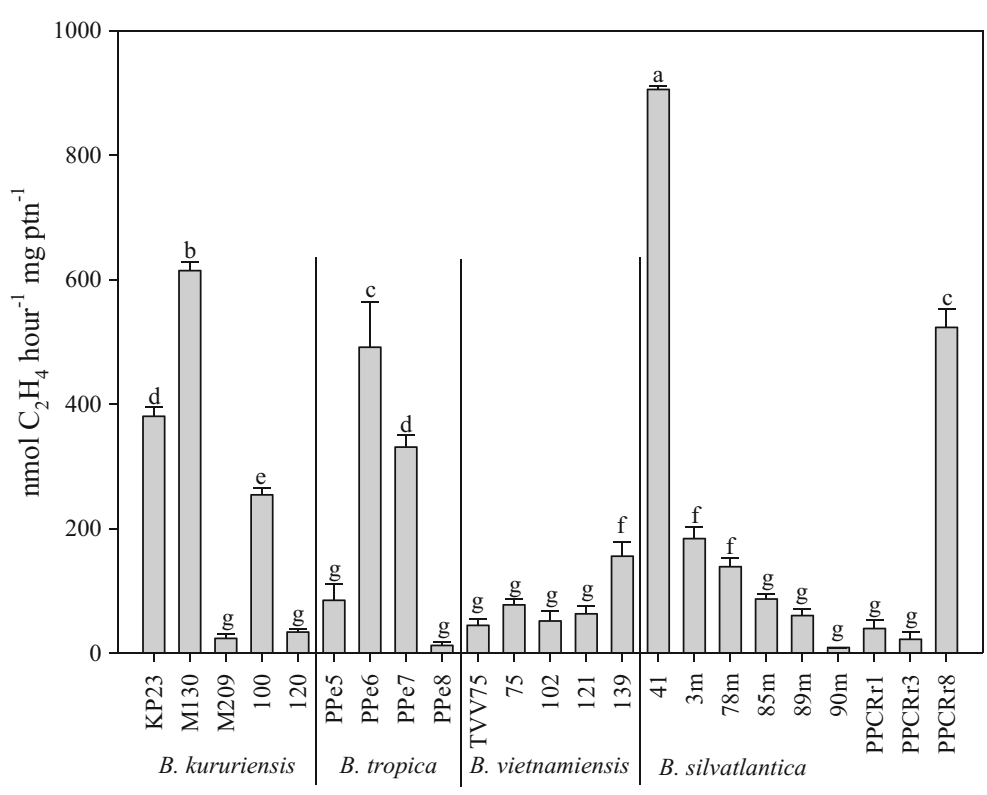

Strains of Burkholderia spp. group. No $B$. vietnamiensis was included in this group or strains were isolated from maize plants.

Two maize genotypes were used in the greenhouse experiments, namely the SHS5050 hybrid and the BRS4157 variety. When a sterile substrate was used, SHS5050 produced 6 times less shoot dry mass in the control without nitrogen in comparison to the treatment fertilized with $40 \mathrm{~kg} \mathrm{~N} \mathrm{ha}^{-1}$ (Table 2). The maize variety was less sensitive to nitrogen absence and it produced 4.7 times less shoot biomass in the control in comparison to that of the high $\mathrm{N}$ level (Table 3). Both genotypes linearly responded to $\mathrm{N}$ fertilization (Tables 2 and 3).

The inoculation of the 23 strains in the SHS5050 maize hybrid was measured under greenhouse condition using sterile substrate (Table 2). All tested bacteria received $20 \mathrm{mg} \mathrm{N}$ per pot during the assay and the inoculation resulted in higher biomass production of aerial tissue in 15 strains, in comparison to that of the high $\mathrm{N}$ level. All B. vietnamiensis, B. tropica and almost all $B$. silvatlantica produced as much as the control with $40 \mathrm{~kg} \mathrm{~N} \mathrm{ha}^{-1}$, i.e., with half $\mathrm{N}$ application. Root dry mass was less responsive and only three strains B. kururiensis M130 and M209 and B. tropica PPe7 showed root biomass improvement comparison to the control with high $\mathrm{N}$ level. Root area and root length did not differ among treatments. The $\mathrm{N}$ content differed among the strains, but two of them - B. vietnamiensis 139 and B. silvatlantica PPCRr8 - showed the same value as the control when the higher dose of fertilizer was applied. None of the 23 strains accumulated as much nitrogen as the control with $40 \mathrm{~kg}$ of $\mathrm{N}$ fertilizer.

The differences in the BRS4157 maize variety growth parameters were less pronounced compared to the hybrid (Table 3). Four strains promoted growth of aerial plant tissue when they were compared to the control with higher $\mathrm{N}$ fertilizer application, namely B. kururiensis M130 and 120 isolated from rice, B. tropica PPe5 and PPe6 isolated from sugarcane. Root dry biomass was improved by a single strain, $B$. vietnamiensis strain 102 isolated from rice. Root area and root length were stimulated by five strains: 100 , PPe5, 102, $3 \mathrm{~m}$ and $85 \mathrm{~m}$ and they had higher root positive effect than the control with $40 \mathrm{~kg}$ of $\mathrm{N}$ fertilizer. Besides that to root area, the PPe5 strain showed positive effect. Compared to the uninoculated control with $40 \mathrm{~kg}$ of $\mathrm{N}$ fertilizer, none of the 23 strains showed $\mathrm{N}$ content or accumulated $\mathrm{N}$ as much nitrogen as the control with $40 \mathrm{~kg}$ of $\mathrm{N}$ fertilizer.

Eleven strains selected from the data of the sterile experiment performed on both varieties were evaluated under soil condition. Two B. kururiensis, M130 and 120, one B. tropica PPe6, one B. vietnamiensis 139 and seven $B$. silvatlantica were the least studied species with no data regarding their application on maize plants available (Tables 4 and 5). As for the pot experiment with soil substrate, SHS5050 maize hybrid did not 
Table 2 Plant growth parameters of maize hybrid SHS5050 grown in sterile substrate 40 days after emergence

\begin{tabular}{|c|c|c|c|c|c|c|}
\hline Treatments & SDM (g) & RDM (g) & $\mathrm{RA}\left(\mathrm{cm}^{2}\right)$ & $\mathrm{RL}(\mathrm{cm})$ & $\% \mathrm{~N}$ & Total N $\left(\mathrm{g} \mathrm{pot}^{-1}\right)$ \\
\hline \multicolumn{7}{|l|}{ B. kururiensis } \\
\hline $\mathrm{KP} 23^{\mathrm{T}}$ & $1.53 \mathrm{a}$ & $0.52 \mathrm{~b}$ & 264.83 & 45.56 & $0.69 \mathrm{c}$ & $0.011 \mathrm{c}$ \\
\hline M130 & $1.94 \mathrm{a}$ & $0.62 \mathrm{a}$ & 318.05 & 51.87 & $0.62 \mathrm{c}$ & $0.012 \mathrm{~b}$ \\
\hline M209 & $1.65 \mathrm{a}$ & $0.63 \mathrm{a}$ & 270.31 & 43.00 & $0.71 \mathrm{c}$ & $0.012 \mathrm{~b}$ \\
\hline 100 & $1.19 \mathrm{~b}$ & $0.44 \mathrm{~b}$ & 260.25 & 43.65 & $0.66 \mathrm{c}$ & $0.008 \mathrm{c}$ \\
\hline 120 & $1.65 \mathrm{a}$ & $0.55 \mathrm{~b}$ & 288.13 & 45.83 & $0.68 \mathrm{c}$ & $0.011 \mathrm{c}$ \\
\hline \multicolumn{7}{|l|}{ B. tropica } \\
\hline PPe5 & $1.48 \mathrm{a}$ & $0.58 \mathrm{~b}$ & 292.93 & 38.19 & $0.76 \mathrm{~b}$ & $0.011 \mathrm{~b}$ \\
\hline PPe6 & $1.69 \mathrm{a}$ & $0.61 \mathrm{~b}$ & 228.65 & 38.83 & $0.78 \mathrm{~b}$ & $0.013 \mathrm{~b}$ \\
\hline PPe7 & $1.66 \mathrm{a}$ & $0.62 \mathrm{a}$ & 258.34 & 44.47 & $0.73 \mathrm{c}$ & $0.012 \mathrm{~b}$ \\
\hline $\mathrm{PPe} 8^{\mathrm{T}}$ & $1.49 \mathrm{a}$ & $0.58 \mathrm{~b}$ & 370.20 & 58.70 & $0.74 \mathrm{~b}$ & $0.011 \mathrm{c}$ \\
\hline \multicolumn{7}{|l|}{ B. vietnamiensis } \\
\hline TVV75 & $1.27 \mathrm{~b}$ & $0.47 \mathrm{~b}$ & 260.88 & 42.26 & $0.61 \mathrm{c}$ & $0.008 \mathrm{c}$ \\
\hline 75 & $1.02 \mathrm{~b}$ & $0.38 \mathrm{~b}$ & 226.81 & 36.55 & $0.61 \mathrm{c}$ & $0.006 \mathrm{c}$ \\
\hline 102 & $1.35 \mathrm{~b}$ & $0.45 \mathrm{~b}$ & 274.85 & 48.17 & $0.70 \mathrm{c}$ & $0.009 \mathrm{c}$ \\
\hline 121 & $1.18 \mathrm{~b}$ & $0.46 \mathrm{~b}$ & 244.08 & 39.43 & $0.68 \mathrm{c}$ & $0.008 \mathrm{c}$ \\
\hline 139 & $1.42 \mathrm{a}$ & $0.59 \mathrm{~b}$ & 278.59 & 39.22 & $0.85 \mathrm{a}$ & $0.012 \mathrm{~b}$ \\
\hline \multicolumn{7}{|l|}{ B. silvatlantica } \\
\hline 41 & $1.53 \mathrm{a}$ & $0.53 \mathrm{~b}$ & 281.56 & 52.79 & $0.65 \mathrm{c}$ & $0.010 \mathrm{c}$ \\
\hline $3 \mathrm{~m}$ & $1.24 \mathrm{~b}$ & $0.52 \mathrm{~b}$ & 292.35 & 43.51 & $0.67 \mathrm{c}$ & $0.008 \mathrm{c}$ \\
\hline $78 \mathrm{~m}$ & $1.51 \mathrm{a}$ & $0.58 \mathrm{~b}$ & 335.30 & 47.92 & $0.68 \mathrm{c}$ & $0.010 \mathrm{c}$ \\
\hline $85 \mathrm{~m}$ & $1.35 \mathrm{~b}$ & $0.54 \mathrm{~b}$ & 277.23 & 36.12 & $0.68 \mathrm{c}$ & $0.012 \mathrm{~b}$ \\
\hline $89 \mathrm{~m}$ & $1.71 \mathrm{a}$ & $0.61 \mathrm{~b}$ & 326.18 & 48.31 & $0.68 \mathrm{c}$ & $0.012 \mathrm{~b}$ \\
\hline $90 \mathrm{~m}$ & $1.61 \mathrm{a}$ & $0.59 \mathrm{~b}$ & 291.95 & 50.30 & $0.68 \mathrm{c}$ & $0.011 \mathrm{c}$ \\
\hline PPCRr1 & $1.73 \mathrm{a}$ & $0.60 \mathrm{~b}$ & 371.51 & 60.42 & $0.78 \mathrm{~b}$ & $0.013 \mathrm{~b}$ \\
\hline PPCRr3 & $1.24 \mathrm{~b}$ & $0.50 \mathrm{~b}$ & 333.33 & 52.27 & $0.78 \mathrm{~b}$ & $0.010 \mathrm{c}$ \\
\hline PPCRr8 & $1.55 \mathrm{a}$ & $0.49 \mathrm{~b}$ & 239.25 & 36.75 & $0.83 \mathrm{a}$ & $0.013 \mathrm{~b}$ \\
\hline \multicolumn{7}{|c|}{ Control uninoculated } \\
\hline T0 & $0.37 \mathrm{c}$ & $0.25 \mathrm{c}$ & 151.57 & 26.95 & $0.70 \mathrm{c}$ & $0.003 \mathrm{c}$ \\
\hline $\mathrm{T} 20$ & $1.39 \mathrm{~b}$ & $0.50 \mathrm{~b}$ & 265.06 & 42.53 & $0.75 \mathrm{~b}$ & $0.010 \mathrm{c}$ \\
\hline $\mathrm{T} 40$ & $2.33 \mathrm{a}$ & $0.71 \mathrm{a}$ & 375.34 & 59.68 & $0.95 \mathrm{a}$ & $0.022 \mathrm{a}$ \\
\hline Overall mean & 1.60 & 0.55 & 283.67 & 45.41 & 0.72 & 0.011 \\
\hline $\mathrm{CV} \%$ & 23.63 & 26.53 & 29.74 & 32.81 & 11.00 & 37.23 \\
\hline
\end{tabular}

T0 absolute control; T20 control with $20 \mathrm{~kg} \mathrm{ha}^{-1} \mathrm{~N}$; T40 control with $40 \mathrm{~kg} \mathrm{ha}^{-1} \mathrm{~N}$; SDM shoot dry matter; RDM root dry matter; RA root area; RL root length; \% N N content of the aerial part; Total N = cumulative nitrogen in the aerial part. Means of four replications. Means in the same columns followed by the same letter, or no letter, do not differ at $p<0.05$ (Scott-Knott test)

respond to nitrogen application in any of the evaluated parameters, thus showing that the soil used as substrate was not limited by $\mathrm{N}$ for plant development during the 40-day experimental period as all inoculated treatments received the equivalent to $20 \mathrm{~kg} \mathrm{~N} \mathrm{ha}^{-1}$ (Table 4). On the other hand, inoculation showed the positive effect of six strains on the biomass accumulation of aerial plant tissue and the positive effect of four strains on root dry mass. In general, B. kururiensis strain 120, B. vietnamiensis $\mathrm{M} 139$ and B. silvatlantica PPCRr8 improved almost all the evaluated parameters, excepted for $\%$ of $N$ (Table 4). Strain 41 from B. silvatlantica improved dry mass accumulation in the entire plant but not in the root area, length or N. Strain M130 produced 
Table 3 Plant growth parameters of maize variety BRS4157 grown in sterile substrate 40 days after emergence

\begin{tabular}{|c|c|c|c|c|c|c|}
\hline Treatments & $\operatorname{SDM}(\mathrm{g})$ & RDM (g) & $\mathrm{RA}\left(\mathrm{cm}^{2}\right)$ & $\mathrm{RL}(\mathrm{cm})$ & $\% \mathrm{~N}$ & Total N $\left(\mathrm{g} \mathrm{pot}^{-1}\right)$ \\
\hline \multicolumn{7}{|l|}{ B. kururiensis } \\
\hline $\mathrm{KP} 23^{\mathrm{T}}$ & $1.52 \mathrm{~b}$ & $0.42 \mathrm{c}$ & $375.95 \mathrm{~b}$ & $54.13 \mathrm{~b}$ & $0.90 \mathrm{~b}$ & $0.014 \mathrm{c}$ \\
\hline M130 & $2.10 \mathrm{a}$ & $0.40 \mathrm{c}$ & $343.71 \mathrm{~b}$ & $47.42 \mathrm{~b}$ & $0.96 \mathrm{~b}$ & $0.020 \mathrm{~b}$ \\
\hline M209 & $1.03 \mathrm{c}$ & $0.44 \mathrm{c}$ & $317.14 \mathrm{~b}$ & $42.08 \mathrm{~b}$ & $0.75 \mathrm{c}$ & $0.009 \mathrm{~d}$ \\
\hline 100 & $0.88 \mathrm{c}$ & $0.67 \mathrm{~b}$ & $729.82 \mathrm{a}$ & $105.75 \mathrm{a}$ & $0.97 \mathrm{~b}$ & $0.009 \mathrm{~d}$ \\
\hline 120 & $2.41 \mathrm{a}$ & $0.65 \mathrm{~b}$ & $514.83 \mathrm{~b}$ & $64.22 \mathrm{~b}$ & $0.82 \mathrm{c}$ & $0.020 \mathrm{~b}$ \\
\hline \multicolumn{7}{|l|}{ B. tropica } \\
\hline PPe5 & $1.87 \mathrm{a}$ & $1.30 \mathrm{a}$ & $597.23 \mathrm{a}$ & $77.23 \mathrm{~b}$ & $0.96 \mathrm{~b}$ & $0.018 \mathrm{~b}$ \\
\hline PPe6 & $2.47 \mathrm{a}$ & $0.83 \mathrm{~b}$ & $471.76 \mathrm{~b}$ & $61.61 \mathrm{~b}$ & $0.93 \mathrm{~b}$ & $0.022 \mathrm{~b}$ \\
\hline PPe7 & $1.59 \mathrm{~b}$ & $0.80 \mathrm{~b}$ & $424.14 \mathrm{~b}$ & $53.17 \mathrm{~b}$ & $1.02 \mathrm{~b}$ & $0.016 \mathrm{c}$ \\
\hline $\mathrm{PPe} 8^{\mathrm{T}}$ & $1.46 \mathrm{~b}$ & $0.47 \mathrm{c}$ & $399.96 \mathrm{~b}$ & $58.72 \mathrm{~b}$ & $0.82 \mathrm{c}$ & $0.013 \mathrm{c}$ \\
\hline \multicolumn{7}{|l|}{ B. vietnamiensis } \\
\hline $\mathrm{TVV}^{\mathrm{T}} 5^{\mathrm{T}}$ & $1.25 \mathrm{~b}$ & $0.42 \mathrm{c}$ & $355.66 \mathrm{~b}$ & $44.46 \mathrm{~b}$ & $0.99 \mathrm{~b}$ & $0.013 \mathrm{c}$ \\
\hline 75 & $0.46 \mathrm{c}$ & $0.32 \mathrm{c}$ & $427.19 \mathrm{~b}$ & $74.40 \mathrm{~b}$ & $1.03 \mathrm{~b}$ & $0.005 \mathrm{~d}$ \\
\hline 102 & $1.34 \mathrm{~b}$ & $1.13 \mathrm{a}$ & $810.86 \mathrm{a}$ & $119.82 \mathrm{a}$ & $1.00 \mathrm{~b}$ & $0.013 \mathrm{c}$ \\
\hline 121 & $1.24 \mathrm{~b}$ & $0.89 \mathrm{~b}$ & $341.33 \mathrm{~b}$ & $45.21 \mathrm{~b}$ & $1.04 \mathrm{~b}$ & $0.013 \mathrm{c}$ \\
\hline 139 & $1.29 \mathrm{~b}$ & $0.42 \mathrm{c}$ & $330.24 \mathrm{~b}$ & $45.70 \mathrm{~b}$ & $1.01 \mathrm{~b}$ & $0.014 \mathrm{c}$ \\
\hline \multicolumn{7}{|l|}{ B. silvatlantica } \\
\hline 41 & $1.51 \mathrm{~b}$ & $0.58 \mathrm{c}$ & $427.08 \mathrm{~b}$ & $64.47 \mathrm{~b}$ & $0.93 \mathrm{~b}$ & $0.014 \mathrm{c}$ \\
\hline $3 \mathrm{~m}$ & $1.44 \mathrm{~b}$ & $0.90 \mathrm{~b}$ & $675.71 \mathrm{a}$ & $88.70 \mathrm{a}$ & $1.00 \mathrm{~b}$ & $0.014 \mathrm{c}$ \\
\hline $78 \mathrm{~m}$ & $0.84 \mathrm{c}$ & $0.70 \mathrm{~b}$ & $467.49 \mathrm{~b}$ & $66.55 \mathrm{~b}$ & $0.96 \mathrm{~b}$ & $0.008 \mathrm{~d}$ \\
\hline $85 \mathrm{~m}$ & $1.21 \mathrm{~b}$ & $0.82 \mathrm{~b}$ & $679.69 \mathrm{a}$ & $104.60 \mathrm{a}$ & $1.00 \mathrm{~b}$ & $0.012 \mathrm{c}$ \\
\hline $89 \mathrm{~m}$ & $1.13 \mathrm{~b}$ & $0.68 \mathrm{~b}$ & $347.14 b$ & $47.38 \mathrm{~b}$ & $0.99 \mathrm{~b}$ & $0.011 \mathrm{c}$ \\
\hline $90 \mathrm{~m}$ & $1.46 \mathrm{~b}$ & $0.79 \mathrm{~b}$ & $451.09 \mathrm{~b}$ & $68.51 \mathrm{~b}$ & $0.96 \mathrm{~b}$ & $0.014 \mathrm{c}$ \\
\hline PPCRr1 & $1.62 \mathrm{~b}$ & $0.85 \mathrm{~b}$ & $391.92 b$ & $51.56 \mathrm{~b}$ & $0.96 \mathrm{~b}$ & $0.015 \mathrm{c}$ \\
\hline PPCRr3 & $0.81 \mathrm{c}$ & $0.49 \mathrm{c}$ & $430.05 \mathrm{~b}$ & $61.05 \mathrm{~b}$ & $1.02 \mathrm{~b}$ & $0.008 \mathrm{~d}$ \\
\hline PPCRr8 & $1.29 \mathrm{~b}$ & $0.43 \mathrm{c}$ & $394.64 \mathrm{~b}$ & $51.74 \mathrm{~b}$ & $1.05 \mathrm{~b}$ & $0.013 \mathrm{c}$ \\
\hline \multicolumn{7}{|c|}{ Control uninoculated } \\
\hline $\mathrm{T} 0$ & $0.53 \mathrm{c}$ & $0.35 \mathrm{c}$ & $318.39 \mathrm{~b}$ & $49.22 \mathrm{~b}$ & $0.73 \mathrm{c}$ & $0.004 \mathrm{~d}$ \\
\hline $\mathrm{T} 20$ & $1.26 \mathrm{~b}$ & $0.70 \mathrm{~b}$ & $444.94 \mathrm{~b}$ & $59.63 \mathrm{~b}$ & $0.99 \mathrm{~b}$ & $0.012 \mathrm{c}$ \\
\hline $\mathrm{T} 40$ & $2.51 \mathrm{a}$ & $0.70 \mathrm{~b}$ & $459.13 \mathrm{~b}$ & $58.23 \mathrm{~b}$ & $1.54 \mathrm{a}$ & $0.039 \mathrm{a}$ \\
\hline Overall mean & 1.41 & 0.66 & 457.56 & 64.08 & 0.97 & 0.014 \\
\hline $\mathrm{CV} \%$ & 31.03 & 32.72 & 32.09 & 37.27 & 12.28 & 31.28 \\
\hline
\end{tabular}

T0 absolute control; T20 control with $20 \mathrm{~kg} \mathrm{ha}^{-1} \mathrm{~N}$; T40 control with $40 \mathrm{~kg} \mathrm{ha}^{-1} \mathrm{~N}$; SDM shoot dry matter; RDM root dry matter; RA root area; RL root length; $\% \mathrm{~N}=\mathrm{N}$ content of the aerial part; Total $\mathrm{N}=$ cumulative nitrogen in the aerial part. Means of four replications Means in the same columns followed by the same letter, or no letter, do not differ at $p<0.05$ (Scott-Knott test)

$18 \%$ more aerial dry mass than the control with half of nitrogen under sterile condition and $14 \%$ in soil substrate (Tables 2 and 4). B. kururiensis 41 also produced $10 \%$ more aerial plant mass in sterile substrate and $13 \%$ in soil using SHS5050 genotype.

The BRS4157 maize variety did not respond to Nfertilizer in plant dry mass. However, the $\mathrm{N} \%$ showed that this experiment produced more dry mass with zero $\mathrm{N}$ than it did with $20 \mathrm{~kg}$ of $\mathrm{N}$-addition (Table 5). Therefore, all comparison will be performed against the control with $40 \mathrm{~kg} \mathrm{~N}$. Three strains showed positive increment in this variety: M130, 139 and 41. The last one specially produced $31 \%$ more aerial plant dry mass than the control. Root dry mass was also positively 
Table 4 Plant growth parameters of maize hybrid SHS5050 grown in soil samples of a Typic Hapladult (A horizon) 40 days after emergence

\begin{tabular}{|c|c|c|c|c|c|c|}
\hline Treatments & $\operatorname{SDM}(\mathrm{g})$ & RDM (g) & $\mathrm{RA}\left(\mathrm{cm}^{2}\right)$ & $\mathrm{RL}(\mathrm{cm})$ & $\% \mathrm{~N}$ & Total N ( g pot $\left.^{-1}\right)$ \\
\hline \multicolumn{7}{|l|}{ B. kururiensis } \\
\hline M130 & $14.31 \mathrm{a}$ & $4.99 \mathrm{~b}$ & $267.84 \mathrm{a}$ & $30.53 \mathrm{~b}$ & 1.91 & $0.274 \mathrm{a}$ \\
\hline 120 & $15.95 \mathrm{a}$ & $5.97 \mathrm{a}$ & $303.92 \mathrm{a}$ & $36.52 \mathrm{a}$ & 1.99 & $0.318 \mathrm{a}$ \\
\hline \multicolumn{7}{|l|}{ B. tropica } \\
\hline PPe6 & $11.76 \mathrm{~b}$ & $4.43 \mathrm{~b}$ & $232.71 \mathrm{~b}$ & $25.05 \mathrm{~b}$ & 1.83 & $0.215 \mathrm{~b}$ \\
\hline \multicolumn{7}{|l|}{ B. vietnamiensis } \\
\hline 139 & $15.62 \mathrm{a}$ & $6.29 \mathrm{a}$ & $324.62 \mathrm{a}$ & $37.78 \mathrm{a}$ & 1.82 & $0.285 \mathrm{a}$ \\
\hline \multicolumn{7}{|l|}{ B. silvatlantica } \\
\hline 41 & $14.14 \mathrm{a}$ & $5.09 \mathrm{a}$ & $199.31 \mathrm{~b}$ & $21.88 \mathrm{~b}$ & 1.77 & $0.251 \mathrm{~b}$ \\
\hline $3 \mathrm{~m}$ & $13.06 \mathrm{~b}$ & $4.98 \mathrm{~b}$ & $246.17 \mathrm{~b}$ & $27.86 \mathrm{~b}$ & 1.97 & $0.258 \mathrm{~b}$ \\
\hline $78 \mathrm{~m}$ & $11.98 \mathrm{~b}$ & $4.52 \mathrm{~b}$ & $225.55 \mathrm{~b}$ & $28.09 \mathrm{~b}$ & 2.16 & $0.259 \mathrm{~b}$ \\
\hline $85 \mathrm{~m}$ & $12.74 \mathrm{~b}$ & $4.00 \mathrm{~b}$ & $198.40 \mathrm{~b}$ & $24.86 \mathrm{~b}$ & 2.48 & $0.308 \mathrm{a}$ \\
\hline $89 \mathrm{~m}$ & $13.05 \mathrm{~b}$ & $4.90 \mathrm{~b}$ & $218.53 \mathrm{~b}$ & $25.29 \mathrm{~b}$ & 2.06 & $0.270 \mathrm{a}$ \\
\hline $90 \mathrm{~m}$ & $14.85 \mathrm{a}$ & $4.92 \mathrm{~b}$ & $245.90 \mathrm{~b}$ & $27.28 \mathrm{~b}$ & 2.06 & $0.299 \mathrm{a}$ \\
\hline PPCRr8 & $13.98 \mathrm{a}$ & $6.55 \mathrm{a}$ & $290.85 \mathrm{a}$ & $36.60 \mathrm{a}$ & 1.90 & $0.266 \mathrm{~b}$ \\
\hline \multicolumn{7}{|c|}{ Control uninoculated } \\
\hline T0 & $11.93 \mathrm{~b}$ & $4.35 \mathrm{~b}$ & $223.84 \mathrm{~b}$ & $27.37 \mathrm{~b}$ & 1.84 & $0.217 \mathrm{~b}$ \\
\hline $\mathrm{T} 20$ & $12.50 \mathrm{~b}$ & $4.94 \mathrm{~b}$ & $239.48 \mathrm{~b}$ & $28.45 \mathrm{~b}$ & 1.73 & $0.217 \mathrm{~b}$ \\
\hline $\mathrm{T} 40$ & $12.70 \mathrm{~b}$ & $4.19 \mathrm{~b}$ & $190.41 \mathrm{~b}$ & $20.83 \mathrm{~b}$ & 1.95 & $0.248 \mathrm{~b}$ \\
\hline Overall mean & 13.47 & 5.01 & 243.40 & 28.45 & 1.96 & 0.263 \\
\hline $\mathrm{CV} \%$ & 20.52 & 21.63 & 24.80 & 26.72 & 13.70 & 14.53 \\
\hline
\end{tabular}

T0 absolute control; T20 control with $20 \mathrm{~kg} \mathrm{ha}^{-1} \mathrm{~N}$; T40 control with $40 \mathrm{~kg} \mathrm{ha}^{-1} \mathrm{~N}$; SDM shoot dry matter; RDM root dry matter; RA root area; RL root length; $\% \mathrm{~N}=\mathrm{N}$ content of the aerial part; Total $\mathrm{N}=$ cumulative nitrogen in the aerial part. Means of four replications Means in the same columns followed by the same letter, or no letter, do not differ at $p<0.05$ (Scott-Knott test)

affected by this inoculation, thus showing $7 \%$ increment. Strains 139 and PPCRr8 affected root dry mass and $85 \mathrm{~m}$ resulted in $\mathrm{N} \%$ positive effect (Table 5). None of the strain inoculations differ in nitrogen accumulation because the substrate presented no limitation of this nutrient.

Only a single strain 41 from the $B$. silvatlantica species was selected under field condition. This strain was selected based on the ARA activity (Fig. 2) the aerial dry mass in the greenhouse experiment with SHS5050 hybrid maize in sterile substrate (Table 2) and the soil experiment with both genotypes (Tables 4 and 5). It also stimulated a positive growth response to other parameters (Tables 2, 3, 4, and 5) and belongs to an infrequently studied species. This strain showed positive effect on grain yield using both genotypes under field conditions in the experiment planted at Seropédica, RJ. These genotypes were also tested in the greenhouse experiments (Table 6). The soil used to test this bacterium performance is very poor in nitrogen, so both genotypes received 40 and $80 \mathrm{~kg} \mathrm{ha}^{-1} \mathrm{~N}$ fertilizer to produce approximately 3.8 tonnes of grains per hectare. Both genotypes produced more than $284 \mathrm{~kg}$ grains with a single $B$. silvatlantica application. The variety was more responsive to the applications with the increment of $383 \mathrm{~kg}$ grains than it was to the non-inoculated control (Table 6). As for the SHS5050 hybrid maize, inoculation reduced the $\mathrm{N} \%$ in the grain and variety BRS4157,nitrogen did not differ between treatments. The second experiment conducted at Cerrado region showed higher overall mean of grains and it produced $600 \mathrm{~kg}$ grains per hectare in the inoculated plots (Table 6). Inoculation did not increase grain yield or nitrogen content in this experiment. However, the SHS505 hybrid genotype showed $500 \mathrm{~kg} \mathrm{ha}^{-1}$ increment of grains under zero nitrogen condition. The grain yield increment in both genotypes varied from $300 \mathrm{~kg} \mathrm{ha}^{-1}$ (variety) to $742 \mathrm{~kg} \mathrm{ha}^{-1}$ of grains (hybrid) with $40 \mathrm{~kg}$ nitrogen and inoculation, and it represents more $10 \mathrm{~kg}$ of $\mathrm{N}$ accumulated in this plant part. 
Table 5 Plant growth parameters of maize variety BRS4157 grown in soil samples of a Typic Hapladult (A horizon) 40 days after emergence

\begin{tabular}{|c|c|c|c|c|c|c|}
\hline Treatments & $\mathrm{SDM}(\mathrm{g})$ & RDM (g) & $\mathrm{RA}\left(\mathrm{cm}^{2}\right)$ & $\mathrm{RL}(\mathrm{cm})$ & $\% \mathrm{~N}$ & Total N ( g pot $\left.^{-1}\right)$ \\
\hline \multicolumn{7}{|l|}{ B. kururiensis } \\
\hline M130 & $17.68 \mathrm{a}$ & $6.55 \mathrm{a}$ & 179.73 & 21.67 & $1.49 \mathrm{~b}$ & 0.247 \\
\hline 120 & $16.38 \mathrm{~b}$ & $6.47 \mathrm{a}$ & 164.63 & 18.46 & $1.52 \mathrm{~b}$ & 0.233 \\
\hline \multicolumn{7}{|l|}{ B. tropica } \\
\hline PPe6 & $15.60 \mathrm{~b}$ & $6.36 \mathrm{a}$ & 160.80 & 19.77 & $1.41 \mathrm{~b}$ & 0.221 \\
\hline \multicolumn{7}{|l|}{ B. vietnamiensis } \\
\hline 139 & $18.75 \mathrm{a}$ & $6.66 \mathrm{a}$ & 192.97 & 21.29 & $1.53 \mathrm{~b}$ & 0.268 \\
\hline \multicolumn{7}{|l|}{ B. silvatlantica } \\
\hline 41 & $20.79 \mathrm{a}$ & $6.77 \mathrm{a}$ & 194.15 & 22.87 & $1.38 \mathrm{~b}$ & 0.281 \\
\hline $3 \mathrm{~m}$ & $13.63 \mathrm{~b}$ & $5.57 \mathrm{~b}$ & 169.36 & 17.91 & $1.74 \mathrm{~b}$ & 0.239 \\
\hline $78 \mathrm{~m}$ & $15.59 \mathrm{~b}$ & $5.63 \mathrm{~b}$ & 162.78 & 19.18 & $1.63 \mathrm{~b}$ & 0.248 \\
\hline $85 \mathrm{~m}$ & $16.01 \mathrm{~b}$ & $4.87 \mathrm{~b}$ & 152.41 & 18.43 & $2.31 \mathrm{a}$ & 0.361 \\
\hline $89 \mathrm{~m}$ & $15.53 \mathrm{~b}$ & $5.75 \mathrm{~b}$ & 160.78 & 17.95 & $1.66 \mathrm{~b}$ & 0.258 \\
\hline $90 \mathrm{~m}$ & $16.14 \mathrm{~b}$ & $6.11 \mathrm{a}$ & 190.73 & 19.80 & $1.63 \mathrm{~b}$ & 0.262 \\
\hline PPCRr8 & $16.71 \mathrm{~b}$ & $6.88 \mathrm{a}$ & 212.23 & 28.00 & $1.53 \mathrm{~b}$ & 0.240 \\
\hline \multicolumn{7}{|c|}{ Control uninoculated } \\
\hline T0 & $13.71 \mathrm{~b}$ & $4.20 \mathrm{~b}$ & 118.63 & 14.34 & $1.99 \mathrm{a}$ & 0.267 \\
\hline $\mathrm{T} 20$ & $15.81 \mathrm{~b}$ & $6.33 \mathrm{a}$ & 172.92 & 20.20 & $1.70 \mathrm{~b}$ & 0.267 \\
\hline $\mathrm{T} 40$ & $15.68 \mathrm{~b}$ & $5.70 \mathrm{~b}$ & 161.80 & 19.17 & $2.02 \mathrm{a}$ & 0.317 \\
\hline Overall mean & 16.29 & 5.99 & 170.99 & 19.93 & 1.68 & 0.265 \\
\hline $\mathrm{CV} \%$ & 22.17 & 25.01 & 32.41 & 24.60 & 21.23 & 21.73 \\
\hline
\end{tabular}

T0 absolute control; T20 control with $20 \mathrm{~kg} \mathrm{ha}^{-1} \mathrm{~N}$; T40 control with $40 \mathrm{~kg} \mathrm{ha}^{-1} \mathrm{~N}$; SDM shoot dry matter; RDM root dry matter; RA root area; $\mathrm{RL}$ root length; $\% \mathrm{~N}=\mathrm{N}$ content of the aerial part; Total $\mathrm{N}=$ cumulative nitrogen in the aerial part. Means of four replications. Means in the same columns followed by the same letter, or no letter, do not differ at $p<0.05$ (Scott-Knott test)

\section{Discussion}

Burkholderia is a well-known bacterial genus used for different purposes, such as inoculant for plant application. Plant growth promotion can be caused by several mechanisms (Luvizotto et al. 2010; Castro-Gonzalez et al. 2011; Naveed et al. 2014). It is well accepted that there are two main groups formed by these 89 described species but only part of these species were exemplified in Fig. 1, the close related ones. The first group is considered to be formed by environmental isolates originated from plant and soil samples. The second one includes the origin of genus Burkholderia, and the B. cepacia complex (BCC) which holds the animal and human pathogen species, including B. vietnamiensis (Suárez-Moreno et al. 2012). Data presented in the current study contributed to these analyses due to their significant bootstrap values higher than 90 (Fig. 1). Growth promotion may be associated with different mechanisms including BNF as well as with other direct and indirect processes. Siderophore has been found in B. tropica, B. silvatlantica and B. kururiensis (Caballero-Mellado et al. 2007; Sessitsch et al. 2005). Castro-Gonzalez et al. (2011) also identified several Bukholderia species associated with sugarcane in México and they quantified the production of IAA, siderophore and phosphate solubilization in vitro by $B$. tropica, B. unamae, B. caribensis and B. vietnamiensis; species isolated from several sugarcane varieties. Ninety-five out of the 398 obtained isolates were diazotrophs and they were tested using the ARA activity as well as the nif $H$ gene amplification method. The $B$. vietnamiensis strain $\mathrm{AR}$ 1122 had positive effect on rice cultivar Arroz 70 under greenhouse and field experiment conditions. However, it did not have the same effect on other 11 cultivars under gnotobiotic conditions, on six cultivars under pot experiments or on at least three cultivars under field conditions 
Table 6 Maize grain yield and nitrogen content of two genotypes SHS5050 and BRS4157 inoculated with Burkholderia silvatlantica strain 41 and cultivated in two different soil conditions

\begin{tabular}{|c|c|c|c|c|c|c|c|c|c|}
\hline \multirow[t]{2}{*}{ Genotype/N fertilization $\left(\mathrm{kg} \mathrm{ha}^{-1}\right)$} & \multicolumn{3}{|c|}{ Grain Yield at $13 \%$ humidity $\left(\mathrm{kg} \mathrm{ha}^{-1}\right)$} & \multicolumn{3}{|c|}{$\% \mathrm{~N}$ in the grain } & \multicolumn{3}{|c|}{ Total- $\mathrm{N}$ in grain $\left(\mathrm{kg} \mathrm{ha}^{-1}\right)$} \\
\hline & $\mathrm{UN}$ & $\mathrm{I}$ & R.V. & $\mathrm{UN}$ & I & R.V. & UN & I & R.V. \\
\hline \multicolumn{10}{|c|}{ Embrapa Agrobiologia, Seropédica, Rio de Janeiro, Brazil } \\
\hline SHS5050 & $4083 \mathrm{~b}$ & $4269 \mathrm{a}$ & 185.6 & $1.73 \mathrm{a}$ & $1.55 \mathrm{~b}$ & $-0,18$ & 71,08 & 67.02 & -4.06 \\
\hline 40 & 3775 & 4001 & 226.0 & 1.58 & 1.37 & $-0,21$ & 59.54 & 55.28 & -4.26 \\
\hline 80 & 4391 & 4537 & 145.2 & 1.88 & 1.73 & $-0,15$ & 82.61 & 78.75 & -3.86 \\
\hline BRS4157 & $3525 \mathrm{~b}$ & 3908 a & 382.7 & 1.66 & 1.71 & 0,05 & 58.50 & 67.14 & 8.64 \\
\hline 40 & 3297 & 3792 & 494.4 & 1.73 & 1.78 & 0,05 & 57.08 & 68.14 & 11.06 \\
\hline 80 & 3752 & 4024 & 271.1 & 1.60 & 1.64 & 0,04 & 59.92 & 66.15 & 6.23 \\
\hline Overall mean & $3804 \mathrm{~b}$ & $4088 \mathrm{a}$ & 284.2 & 1.70 & 1.63 & $-0,07$ & 64.79 & 67.08 & 2.29 \\
\hline $\mathrm{CV} \%$ & 9.23 & & & 8.72 & & & 16.39 & & \\
\hline \multicolumn{10}{|c|}{ Embrapa Cerrado, Planaltina, Distrito Federal, Brazil } \\
\hline SHS5050 & 4243 & 4750 & 507.2 & 1.52 & 1.57 & 0.05 & 64.44 & 74.48 & 10.04 \\
\hline 40 & 3674 & 4417 & 742.8 & 1.49 & 1.53 & 0.04 & 54.60 & 67.59 & 12.98 \\
\hline 80 & 4811 & 5083 & 271.6 & 1.54 & 1.60 & 0.06 & 74.28 & 81.38 & 7.10 \\
\hline BRS4157 & 4569 & 4576 & 7.5 & 1.60 & 1.75 & 0.15 & 73.28 & 80.05 & 6.78 \\
\hline 40 & 4674 & 4981 & 306.9 & 1.65 & 1.76 & 0.10 & 77.33 & 87.48 & 10.14 \\
\hline 80 & 4463 & 4172 & -291.8 & 1.55 & 1.74 & 0.19 & 69.22 & 72.63 & 3.41 \\
\hline Overall mean & 4406 & 4663 & 257.4 & 1.56 & 1.66 & 0.09 & 68.86 & 77.27 & 8.41 \\
\hline $\mathrm{CV} \%$ & 24.22 & & & 9.13 & & & 24.74 & & \\
\hline
\end{tabular}

UN uninoculated treatment; I inoculated treatment with strain 41. R.V relative value of Inoc - Control. Means of four replicates. Means in the same columns followed by the same letter, or no letter, do not differ at $p<0.05$ (Scott-Knott test)

(Araújo et al. 2013). This genotype response was also observed in the tested Burkholderia strains (Tables 2, 3, 4 and 5). Another evidence of genotype response was found by Vargas et al. (2012) that used rice plantlets and measured the ethylene modulation hormonal response to inoculation. Vargas et al. (2012) used B. kururiensis M130 and Azospirillum brasilense Sp 245 inoculation on rice cultivars IR 42 and IAC4440, which were selected based on their response to BNF capability: the first one is responsive and the second is not. Cultivars showed significant increase in lateral root numbers 10 days after the inoculation with $A$. brasilense $\mathrm{Sp} 245$, but plants inoculated with $B$. kururiensis M130 did not.

The Bcc complex includes $B$. vietnamiensis which is a bacteria commonly isolated from the maize rhizosphere worldwide (Balandreau et al. 2001; Fiore et al. 2001; Zhang and Xie 2007). Some field experiments were performed with this species, but mainly with rice inoculation. The first report was done by Tranvan et al. (1994) who used the TVV75 strain in pots containing acid-sulfate soil. The strain was selected according to ARA activity and growth promotion in young plants with $20 \%$ increment in rice grains final yield, similar approach used in this publication. Later on, Van et al. (2000) repeated this use in pots with three different field experiments with rice and again TVV75 improved grain yield. Baldani et al. (2000) compared this species with other Burkholderia isolates. They used gnotobiotic conditions and B. vietnamiensis fixed $19 \%$ of the plant total N. Araújo et al. (2013) tested another strain of $B$. vietnamiensis in a rice crop planted in the Northeast region of Brazil and it presented good association with a single cultivar. This specific interaction between the Burkholderia strain and the plant genotype was also observed with strain 41, under field conditions (Table 6).

Other Burkholderia species has been tested as inoculant in several plant species. Paungfoo-Lonhienne et al. (2014) used one strain and the new diazotrophic species Burkholderia australis and compared them to one strain of Bacillus spp. on sugarcane plantlets. They observed that only $B$. australis enhanced sugarcane root and aerial dry biomass after inoculation and also that the inoculum density had positive effect on root dry weight, and that the aerial plant tissue was less sensitive to high bacterial 
numbers. This might be interpreted as a function of auxin production. The incorporation of ${ }^{15} \mathrm{~N}_{2}$ gas was also performed and it confirmed diazotrophic contribution to sugarcane N supply. Mehnaz et al. (2010) evaluated the effect of Burkholderia phytofirmans E24 and other four strains from different PGPR bacteria on maize var. 39D82 and 39 M27 under greenhouse conditions. They used the same sterile approach followed by soil substrate in order to select the best strain for plant application. B. phytofirmans had positive effect on dry weight under sterile substrate. The strain PsJN has been applied to wheat, maize, tomato, grapevine and potato, it colonizes the rhizosphere and the plant interior, also enhance the root system, leaf area and water use efficient (Compant et al. 2008; Naveed et al. 2013, 2014). It means that the plant origin and plant effect specificities are not observed and it corroborates the present study, in which isolates from rice presented good performance on maize inoculation.

B. tropica presented one of the largest genomes described in an associative bacterium with $8.73 \mathrm{Mbp}\left(\mathrm{PPe} 8^{\mathrm{T}}\right.$ strain) when it was compared with the 7.91 of B. silvatlantica (strain SRMrh20 ${ }^{\mathrm{T}}$ ), with the $6.90 \mathrm{Mbp}$ of B. vietnamiensis (strain MMi302), with the $6.46 \mathrm{Mbp}$ of strain KP23 and with the $6.64 \mathrm{Mbp}$ of strain M130 from B. kururiensis. All of these strains showed two to five replicons (Martinez-Aguilar et al. 2008). Although the selective advantage given by the multireplicons is not clear, some authors described these large genomes as being an advantage to fitness under the environmental conditions that bacteria must face when they are introduced to new hosts or when they are under soil conditions (Mahenthiralingam et al. 2005). The draft genome of strain M130 from B. kururiensis was published in 2013 by Coutinho et al. (2013). They showed that this species has genes that are associated with plant growth promotion such as $a c c D$ gene encoding acc deaminase, indole production and nif genes. They are also associated with genes related to organic substance degradation and detoxification mechanisms.

Several mechanisms are involved in plant growth and bacterial strain selection of Burkholderia can improve plant yield under field conditions. The present data tested four bacterial species and only 23 strains. Data based on the features characterization of the strains and performance under soil condition can improve plant growth e reduce inputs of nitrogen fertilizers and agricultural costs.

Acknowledgments This project was funded by Embrapa $n$. 02.05.1.06.00.01 and 02.09.01.11.00.06 and by INCT/CNPq Proc. no. 573828/2008-3. The authors would like to thank Universidade Federal Rural do Rio de Janeiro and the Brazilian Federal Agency for Support and Evaluation of Graduate Education (CAPES) for granting the postdoctoral scholarship to the first author, as well as the National Council for Scientific and Technological Development $(\mathrm{CNPq})$ for the research scholarship granted to the last author. The study publication was authorized by Embrapa Agrobiologia Editorial Committee of Publication.

\section{Compliance with ethical standards}

Conflict of interest The authors declare no conflicts of interest.

\section{References}

Alves GC, Videira SS, Urquiaga S, Reis VM (2015) Differential plant growth promotion and nitrogen fixation in two genotypes of maize by several Herbaspirillum inoculants. Plant Soil 387:307-321. doi:10.1007/s11104-014-2295-2

Anandham R, Indira Gandhi P, Kwon SW, Sa TM, Kim YK, Jee HJ (2009) Mixotrophic metabolism in Burkholderia kururiensis subsp. Thiooxydans subsp. nov., a facultative chemolithoautotrophic thiosulfate oxidizing bacterium isolated from rhizosphere soil and proposal for classification of the type strain of Burkholderia kururiensis as Burkholderia kururiensis subsp. kururiensis subsp. nov. Arch Microbiol 191:885-894. doi:10.1007/s00203-009-0517-4

Anuar AR, Shemsuddin ZH, Okon Y (1995) Contribution of legume-N by nodulated groundnut for growth of maize on an acid soil. Soil Biol Biochem 27:595-601. doi:10.1016/ 0038-0717(95)98637-4

Araújo AES, Baldani VLD, Galisa PS, Pereira JA, Baldani JI (2013) Response of traditional upland rice varieties to inoculation with selected diazotrophic bacteria isolated from rice cropped at the northeast region of Brazil. Appl Soil Ecol 64: 49-55. doi:10.1016/j.apsoil.2012.10.004

Balandreau J, Viallard V, Cournoyer B, Coenye T, Laevens S, Vandamme P (2001) Burkholderia cepacia genomovar III is a common plant-associated bacterium. Appl Environ Microbiol 67:982-985. doi:10.1128/AEM.67.2.982-985.2001

Baldani VLD, Oliveira E, Balota E, Baldani JI, Kirchhof G, Döbereiner J (1997) Burkholderia brasilensis sp. nov., uma nova espécie de bactéria diazotrófica endofítica. An Acad Bras Cienc 69:116

Baldani VLD, Baldani JI, Döbereiner J (2000) Inoculation of rice plants with the endophytic diazotrophs Herbaspirillum seropedicae and Burkholderia spp. Biol Fertil Soils 30: 485-491. doi:10.1007/s003740050027

Baldani JI, Reis VM, Videira SS, Boddey LH, Baldani VLD (2014) The art of isolating nitrogen-fixing bacteria from non-leguminous plants using $\mathrm{N}$-free semi-solid media: a practical guide for microbiologists. Plant Soil 384:413-431. doi:10.1007/s11104-2186-6

Boddey RM (1987) Methods for quantification of nitrogen fixation associated with gramineae. Crit Rev Plant Sci 6:209266. doi:10.1080/07352688709382251 
Bremner J, Mulvaney C (1982) Nitrogen - total. Methods of soil analysis part 2 chemical and microbiological properties. Meth Soil Anal 2:595-624

Caballero-Mellado J, Onofre-Lemus J, Eestrada-de-Los Santos J, Martinez-Aguilar L (2007) The tomato rhizosphere, an environment rich in nitrogen-fixing Burkholderia species with capabilities of interest for agriculture and bioremediation. Appl Environ Microbiol 73:5308-5319. doi:10.1128/AEM. 00324-07

Castro-Gonzalez R, Martinez-Aguilar L, Ramirez-Trujillo A, Estrada-de Los Santos P, Caballero-Mellado J (2011) High diversity of culturable Burkholderia species associated with sugarcane. Plant Soil 345:155-169. doi:10.1007/s11104011-0768-0

Coenye T, Vandamme P (2003) Diversity and significance of Burkholderia species occupying diverse ecological niches. Environ Microbiol 5:719-729. doi:10.1046/j.1462-2920. 2003.00471.x

Compant S, Nowak J, Coenye T, Clément C, Ait Barka E (2008) Diversity and occurrence of Burkholderia spp. in the natural environment. FEMS Microbiol Rev 32:607-626. doi:10. 1111/j.1574-6976.2008.00113.x

Coutinho BG, Silva DP, Previato JO, Mendonça-Previato L, Venturi V (2013) Draft genome of the rice endophyte Burkholderia kururiensis M130. Genome Announc 1: e00225-e00212. doi:10.1128/genomeA.00225-12

Estrada-De Los Santos P, Bustillos-Cristales R, Caballero-Mellado J (2001) Burkholderia, a genus rich in plant-associated nitrogen fixers with wide environmental and geographic distribution. Appl Environ Microbiol 67:2790-2798. doi:10.1128/ AEM.67.6.2790-2798.2001

Euclydes R (2004) Sistema para análises estatísticas (SAEG 9.0). Viçosa: Funarbe

Fages, J. Azospirillum inoculants and field experiments Y. Okon (Ed.), Azospirillum/plant associations, CRC Press, Boca Raton (1994), pp. 87-109

Ferreira D (2010) Sisvar: versão 5.3. Lavras: UFLA

Fiore A, Laevens S, Bevivino A, Dalmastri C, Tabacchioni S, Vandamme P, Chiarini L (2001) Burkholderia cepacia complex: distribution of genomovars among isolates from the maize rhizosphere in Italy. Environ Microbiol 3:137-143. doi:10.1046/j.1462-2920.2001.00175.x

Gillis M, Trân Van V, Bardin R, Goor M, Hebbar P, Willems A, Segers P, Kersters K, Heulin T, Fernandez MP (1995) Polyphasic taxonomy in the genus Burkholderia leading to an emended description of the genus and proposition of Burkholderia vietnamiensis. sp. nov. for $\mathrm{N}_{2}$-fixing isolates from rice in Vietnam. J Syst Evol Microbiol 45:274-289

Govindarajan M, Balandreau J, Kwon S-W, Weon H-Y, Lakshminarasimhan C (2008) Effects of the inoculation of Burkholderia vietnamensis and related endophytic diazotrophic bacteria on grain yield of rice. Microb Ecol 55:21-37. doi:10.1007/s00248-007-9247-9

Guimarães SL, Campos DTS, Baldani VLD, Jacob-Neto J (2010) Diazotrophic bacteria and nitrogen fertilization in rice cultivars. R Caatinga 23:32-39

Halvorson AD, Peterson GA, Reule CA (2002) Tillage system and crop rotation effects on dry land crop yields and soil carbon in the central great plains. Agron J 94:1429-1436

Hungria M, Campo RJ, Souza EM, Pedrosa FO (2010) Inoculation with selected strains of Azospirillum brasilense and
A. lipoferum improves yields of maize and wheat in Brazil. Plant Soil 331:413-425. doi:10.1007/s11104-009-0262-0

Ikeda AC, Bassani LL, Adamoski D, Stringari D, Cordeiro VK, Glienke C, Steffens MBR, Hungria M, Galli-Terasawa LV (2013) Morphological and genetic characterization of endophytic bacteria isolated from roots of different maize genotypes. Microb Ecol 65:154-160. doi:10.1007/s00248-0120104-0

Kimura M (1980) A simple method for estimating evolutionary rates of base substitutions through comparative studies of nucleotide-sequences. J Mol Evol 16:111-120. doi:10.1007/ Bf01731581

Liu Y, Zuo S, Zou YY, Wang JH (2012) Song W (2012) investigation of diversity and population succession dynamics of indigenous bacteria of the maize spermosphere. World $\mathrm{J}$ Microbiol Biotechnol 28:391-396. doi:10.1007/s11274011-0822-3

Lowry OH, Rosebrough NJ, Farr AL, Randall RJ (1951) Protein measurement with the folin phenol reagent. J Biolumin Chemilumin 193:265-275

Luvizotto D, Marcon J, Andreote F, Dini-Andreote F, Neves A, Araújo W, Pizzirani-Kleiner A (2010) Genetic diversity and plant-growth related features of Burkholderia spp. from sugarcane roots. World J Microbiol Biotechnol 26:1829-1836. doi:10.1007/s11274-010-0364-0

Mahenthiralingam E, Urban TA, Goldberg JB (2005) The multifarious, multireplicon Burkholderia cepacia complex. Nat Rev Microbiol 3:144-156. doi:10.1038/nrmicro1085

Martinez-Aguilar L, Diaz R, Pena-Cabriales JJ, Estrada-de los Santos P, Dunn MF, Caballero-Mellado, J (2008) Multichromosomal genome structure and confirmation of diazotrophy in novel plant-associated Burkholderia species. Appl Environ Microbiol 74:4574-4579. doi:10.1128/AEM. 00201-08

Mattos KA, Padua VL, Romeiro A, Hallack LF, Neves BC, Ulisses TM, Barros CF, Todeschini AR, Previato JO, Mendonca-Previato L (2008) Endophytic colonization of rice (Oryza sativa L.) by the diazotrophic bacterium Burkholderia kururiensis and its ability to enhance plant growth. An Acad Bras Cienc 80:477-493. doi:10.1590/S000137652008000300009

Mehnaz S, Kowalik T, Reynolds B, Lazarovits G (2010) Growth promotion effects of corn (Zea mays) bacterial isolates under greenhouse and field conditions. Soil Biol Biochem 42: 1848-1856. doi:10.1016/j.soilbio.2010.07.003

Montañez A, Blanco AR, Barlocco C, Beracochea M, Sicardi M (2012) Characterization of cultivable putative endophytic plant growth promoting bacteria associated with maize cultivars (Zea mays L.) and their inoculation effects in vitro. Appl Soil Ecol 58:21-28. doi:10.1016/j.apsoil.2012.02.009

Moulin L, Munive A, Dreyfus B, Boivin-Masson C (2001) Nodulation of legumes by members of the beta-subclass of proteobacteria. Nature 411:948-950. doi:10.1038/35091106

Naveed M, Hussain MB, Zahir ZA, Mitter B, Sessitsch A (2013) Drought stress ameliotation in wheat through inoculation with Burkholderia phytofirmans strain PsJN. Plant Growth Regul 73:121-131. doi:10.1007/s10725-013-9874-8

Naveed M, Mitter B, Reichenauer TG, Wieczorek K, Sessitsch A (2014) Increased drought stress resilience of maize through endophytic colonization by Burkolderia phytofirmans PsJN 
and Enterobacter sp FD17. Environ Exp Bot 97:30-39. doi: 10.1016/j.envexpbot.2013.09.014

Oliveira ALM, Canuto EL, Reis VM, Baldani JI (2003) Response of micropropagated sugarcane varieties to inoculation with endophytic diazotrophic bacteria. Braz J Microbiol 34:59-61

Oliveira ALM, Canuto EL, Urquiaga S, Reis VM, Baldani JI (2006) Yield of micropropagated sugarcane varieties in different soil types following inoculation with diazotrophic bacteria. Plant Soil 284:23-32. doi:10.1007/s11104-0060025-0

Paungfoo-Lonhienne C, Lonhienne TGA, Yeoh YK, Webb RI, Lakshmanan P, Chan CH, Lim P-E, Ragan MA, Schmidt S, Hugenholtz P (2014) A new species of Burkholderia isolated from sugarcane roots promotes plant growth. Microb Biotechnol 7:142-154. doi:10.1111/1751-7915.12105

Perin L, Martinez-Aguilar L, Paredes-Valdez G, Baldani JI, Estrada-de Los Santos P, Reis VM, Caballero-Mellado J (2006) Burkholderia silvatlantica sp. nov., a diazotrophic bacterium associated with sugar cane and maize. Int J Syst Evol Microbiol 56:1931-1937. doi:10.1099/ijs.0.64362-0

Reis VM, Estrada-de Los Santos P, Tenorio-Salgado S, Vogel J, Stoffels M, Guyon S, Mavingui P, Baldani VL, Schmid M, Baldani JI, Balandreau J, Hartmann A, Caballero-Mellado J (2004) Burkholderia tropica sp. nov., a novel nitrogen-fixing, plant-associated bacterium. Int J Syst Evol Microbiol 54: 2155-2162. doi:10.1099/ijs.0.02879-0

Rodrigues EP, Rodrigues LS, de Oliveira ALM, Baldani VLD, Teixeira KRD, Urquiaga S, Reis VM (2008) Azospirillum amazonense inoculation: effects on growth, yield and $\mathrm{N}_{2}$ fixation of rice (Oryza sativa L.). Plant Soil 302:249-261. doi:10.1007/s11104-007-9476-1

Rodrigues-Blanco A, Sicardi M, Frioni L (2015) Plant genotype and nitrogen fertilization effects on abundance and diversity of diazotrophic bacteria associated with maize (Zea mays L.). Biol Fertil Soils 51:391-402. doi:10.1007/s00374-014-09868

Roesch LFW, Camargo FAO, Bento FM, Triplett EW (2008) Biodiversity of diazotrophic bacteria within the soil root and stem of field-grown maize. Plant Soil 302:91-104. doi: 10.1007/s11104-007-9458-3

Saitou N, Nei M (1987) The neighbor-joining method - a new method for reconstructing phylogenetic trees. Mol Biol Evol 4:406-425

Schloter M, Bode W, Hartmann A, Beese F (1992) Sensitive chemoluminescence-based immunological quantification of bacteria in soil extracts with monoclonal-antibodies. Soil Biol Biochem 24:399-403. doi:10.1016/0038-0717(92) 90201-8

Schultz N, Morais RF, Silva JA, Baptista RB, Oliveira RP, Leite JM, Pereira W, Carneiro Júnior JB, Alves BJR, Baldani JI, Boddey RM, Urquiga S, Reis VM (2012) Avaliação agronômica de duas variedades de Cana de açúcar inoculadas com bactérias diazotróficas e adubadas com nitrogênio. Pesq Agrop Brasileira 47:261-268

Schultz N, da Silva JA, Sousa JS, Monteiro RC, Oliveira RP, Chaves VA, Pereira W, da Silva MF, Baldani JI, Boddey RM, Reis VM, Urquiaga S (2014) Inoculation of sugarcane with diazotrophic bacteria. Rev Bras Cienc Solo 38:407-414

Sessitsch A, Coenye T, Sturz AV, Vandamme P, Ait Barka E, Salles JF, Van Elsas JD, Faure D, Reiter B, Glick BR, Wang-Pruski G, Nowak J (2005) Burkholderia phytofirman sp. nov., a novel plant-associated bacterium with plant-beneficial properties. Int J Syst Evol Microbiol 55:1187-1192. doi:10.1099/ ijs.0.63149-0

Suárez-Moreno ZR, Caballero-Mellado J, Coutinho BG, Mendonça-Previato L, James EK, Venturi V (2012) Common features of environmental and potentially beneficial plant-associated Burkholderia. Microb Ecol 63:249-266. doi:10.1007/s00248-011-9929-1

Scott A, Knott M (1974) A cluster analysis method for grouping means in the analysis of variance. Biometrics 30:507-512

Tamura K, Peterson D, Peterson N, Stecher G, Nei M, Kumar S (2011) MEGA5: Molecular evolutionary genetics analysis using maximum likelihood, evolutionary distance and maximum parsimony methods. Mol Biol Evol 28:2731-2739. doi:10.1093/molbev/msr121

Thompson JD, Higgins DG, Gibson TJ (1994) Clustal-W - improving the sensitivity of progressive multiple sequence alignment through sequence weighting, position-specific gap penalties and weight matrix choice. Nucleic Acids Res 22:4673-4680. doi:10.1093/nar/22.22.4673

Tranvan V, Mavingui P, Berge O, Balandreau J, Heulin T (1994) Growth promotion of rice after inoculation with a nitrogenfixing bacteria Burkholderia vietnamiensis isolated from an acid-sulfate soil in Vietnam. Agronomie 14:697-707. doi:10. 1051/agro:19941006

Van VT, Berge O, Ke SN, Balandreau J, Heulin T (2000) Repeated beneficial effects of rice inoculation with a strain of Burkholderia vietnamiensis on early and late yield components in low fertility sulphate acid soils of Vietnam. Plant Soil 218:273-284

Vargas L, de Carvalho TLG, Ferreira PCG, Baldani VLD, Baldani JI, Hermerly A (2012) Early responses of rice (Oriza sativa L.) seedlings to inoculation with beneficial diazotrophic bacteria are dependent on plant and bacterial genotypes. Plant Soil 356:127-137. doi:10.1007/s11104-012-1274-8

Zhang L, Xie G (2007) Diversity and distribution of Burkholderia cepacia complex in the rhizosphere of rice and maize. FEMS Microbiol Lett 266:231-235. doi:10.1111/j.1574-6968.2006. 00530.x

Zhang H, Hanada S, Shigematsu T, Shibuya K, Kamagata Y, Kanagata T, Kurame R (2000) Burkholderia kururiensis sp.nov., a trichloroethylene (TCE)-degrading bacterium isolated from an aquifer polluted with TCE. Int J Syst Evol Microbiol 50:743-749 